\title{
Union Membership as a Moderator in the Relationship Between Living Wage, Job Satisfaction and Employee Engagement
}

\author{
M. J. Maleka ${ }^{1}$ - C. M. Schultz ${ }^{2}$ - L. van Hoek ${ }^{2}$ L. Paul-Dachapalli ${ }^{2}$ \\ S. C. Ragadu ${ }^{2}$
}

Accepted: 23 May 2021 / Published online: 4 September 2021

(C) The Author(s) 2021

\begin{abstract}
In many developing countries, lower-level employees are working in workplaces that pay them poverty wages. The need for workers to earn a living wage has long been argued, both within the trade union movement, employers and society, along with the link with job satisfaction and employee engagement. The present study aims to explore the relationship between living wage, job satisfaction and employee engagement, as well as union membership as a moderator in these relationships. A quantitative research approach was employed in this study, and Loess curves were used to graphically predict the relationship between study variables. There were significant relationships between a living wage, job satisfaction and employee engagement. The results indicated that the relationships between the variables were cubic and not linear. Union membership was the moderator in the relationship between living wages and employee involvement. Union membership moderated the cubic relationship between living wages and employee engagement. Union membership also moderated the cubic relationship between living wages and job satisfaction.
\end{abstract}

Keywords Living wage $\cdot$ Job satisfaction $\cdot$ Employee engagement $\cdot$ Union membership $\cdot$ Low-income workers

Disclaimer We hereby declare that the article submitted for publication at is our own work and has not previously been submitted to any other journal for publication.

C. M. Schultz

schultzcm@tut.ac.za

Extended author information available on the last page of the article 


\section{Introduction}

Across both developed and developing economies, there seems to be a disjunction between what is set as a minimum wage and what is needed as a living wage (Prowse et al. 2017). Certain economics literature suggests that indicators like food poverty lines should be used to determine wages (Mohr et al. 2016). This economic argument states that a lower wage is better than nothing and that more employees would be hired when wages are low (Bendix 2015). Current research shows that deindustrialisation, union power reduction and minimum wage implementation increase inequality (Maleka 2018). To a large extent, the literature on the concepts and practices associated with the living wage has focused on developed rather than developing countries (Ford and Gillan 2017). Potential benefits for employers associated with living wage policies include reduced turnover and increased consumer satisfaction (Zuberi 2013). The relationship between union membership and job satisfaction is still disputed vigorously among scholars (Laroche 2017). The need for a current understanding of the dynamics between union membership, living wage, job satisfaction and employee engagement led to the research gap addressed by this study.

The need for workers to earn a living wage has long been argued, both within the trade union movement, employers and society (Sellers 2017). Within its remit, the UK's statutory minimum wage has been a success, but trade unions argue that the rates should be higher, with some also tending towards the view that the minimum wage should increase to become a genuine statutory living wage (TUC 2016). The idea of a regional living wage as a long-term aspiration is compatible with local trade union agendas in Asia (Ford and Gillan 2017). There is contradicting evidence about the role of unions in enhancing employees' satisfaction. It has been reported that unionised employees have lower job satisfaction than non-unionised employees (Renaud 2002; Hammer and Avgar 2005; Green and Heywood 2015). Conversely, Maleka's (2018) study conducted in South Africa used logistic regression to reveal that union employees were more likely to be unionised as compared to non-unionised employees. Another South African study using linear regression found that unionised employees were more engaged than non-unionised employees (Maleka et al. 2017).

Thus far, no study has been conducted in South Africa to measure the relationships between living wage, employee engagement and job satisfaction, with union membership moderating these relationships. At the time this study was conducted, it had not been tested which line (i.e. linear, logarithmic or cubic) best fitted the data when measuring the relationships between living wage, job satisfaction and employee engagement with unions as a moderator. In South Africa, unions are known to negotiate for salary increases that are above inflation rates. Over the past 3 years (2017-2019), the inflation rate has averaged 5\%. The gross domestic product (GDP) per capita for South Africa was \$5596 in 2017, which was the highest in the Southern African Development Community (Maleka et al. 2019). Plecher (2019) established that the GDP per capita was $\$ 9928$ for Brazil, $\$ 10,961.99$ for Russia, $\$ 2014.01$ for India and $\$ 8677.40$ for China. South Africa, 
Brazil, Russia, India and China are known as BRICS, and South Africa is a trade partner with the other member countries. There is no legislation on living wages in these countries.

Unions promote wage equity among employees (Cowherd and Levine 1992; Leete 2000; Western and Rosenfeld 2011), and employees who perceive inequality are more likely to join unions for support. Chang et al. (2017, p. 656) found that "unionized employees perceived less manager-employee consultation, health and safety, dispensability, time flexibility, workload flexibility, managerial trust, fair treatment and pay equity". Sellers (2017, p. 797) is of the opinion that "the real living wage will continue to have moral authority and very likely that it will continue to have success. In these circumstances, it is also very likely to continue to appeal to trade unions as a useful standard that can be used in recruitment and pay bargaining".

\section{Theoretical Background and Hypotheses}

The living wage, therefore, relates to people's subsistence and needs and can be defined as the amount of remuneration that is sufficient to provide a decent standard of living for workers and their families (Ryan 1912).

A living wage should support a basic living standard that is considered decent. Anker (2011, p. 22) gives a modern definition of a living wage:

"remuneration received for a standard work week by a worker in a particular place sufficient to afford a decent standard of living for the worker and her or his family. Elements of a decent standard of living include food, water, housing, education, health care, transport, clothing, and other essential needs, including provision for unexpected events".

The term living wage is used to express the idea that wages should adhere to social norms (Figart 2001).

According to Anker and Anker (2013), the living wage methodology has two main components, each of which is described in more detail in the following. The first component estimates the cost of a basic but decent lifestyle for workers and their families in a particular place. The second component determines whether the estimated living wage is being paid to workers. Estimates of what constitutes a living wage necessarily vary by location and household type.

Living wage London (2014) suggests that there are two steps to calculate living wages:

a. Step 1 Calculating living expenses (the Canadian Living Wage Framework guided London's living expense calculation. The framework identifies eight general expense categories: food, clothing, rental housing, transportation, childcare, medical expenses, one parent taking courses at a local college and other expenses).

b. Step 2 Income calculation (in order to calculate the living wage, it is necessary to calculate the total household employment income needed to cover expenses, after 
taking into account government benefits and credits, taxes, payroll deductions and subsidies).

The Anker method argues that the estimation of living costs should focus on particular locations rather than using flat national living wage estimates in order to improve the accuracy and credibility of living wage calculations, and consequently their uptake and impact (Anker and Anker 2017).

Kumar (2018) mentions three approaches to wages:

a. Subsistence theory of wages The level of wages is just sufficient to meet the necessities of life. The classical economists called this the neutral level of wages, and proponents of this theory believed in the bargaining power of the workers. In such a situation, trade unions play an important role in increasing wages.

b. Marginal productivity theory of wages In equilibrium, each labourer will be rewarded in accordance with marginal productivity.

c. Modern theory of wages Wages are determined by the interaction of market forces of demand and supply.

The living wage theories discussed thus far are from economics and do not cover how wages relate to psychological outcomes or human capabilities such as employee engagement and job satisfaction.

\subsection{Relationship Between Living Wage and Human Capabilities}

Initially developed by the Indian economist and Nobel Prize winner Amartya Sen, the capability approach has contributed to renewing the debates worldwide on inequality and poverty (Sen 1992). The specificity of the capability approach is to emphasise people's real freedom to choose the life they value (Sen 1999). Capabilities can be thought of as the set of options from which people can choose their way of being and doing (Subramanian et al. 2013). Sen's approach provides a specific informational basis of judgement in justice for measuring equality between people, and social arrangements should be primarily evaluated according to the freedom they provide to people to do and be what they value (Sen 1987).

In terms of our study, Fig. 1 shows three opposing living wage theoretical frameworks, i.e. linear, poverty trap and law of diminishing returns. Carr et al. (2018) developed this figure. The black solid lines represent linear theory, which states that the relationship between a living wage and human capability (i.e. job satisfaction) is linear, and this was developed by George (1989) and was validated by Judge et al. (2010). The blue solid line represents a poverty trap and states that there is a living wage threshold (Carr et al. 2018). Employees who earn below the threshold are in poverty, and there is a tendency among them to apply for loans on which they pay exorbitant interest rates (Maleka 2017). The blue dotted or dashed line represents a diminishing returns theory, which says that any wage is better than earning nothing. This theory has been criticised for entrapping employees by what is known as poverty work or earning salaries are below the poverty line (Maleka et al. 2018). 


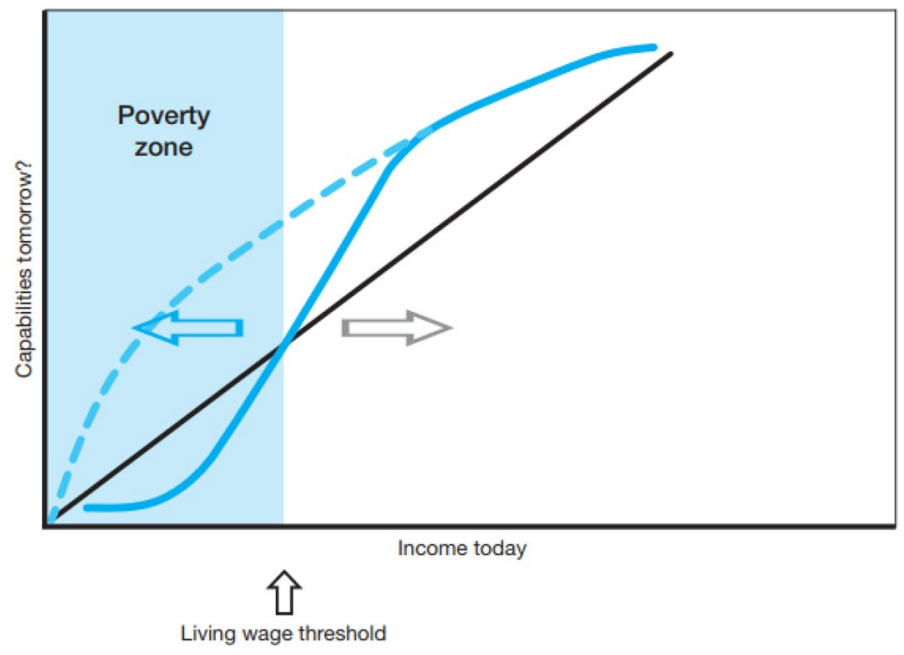

Fig. 1 Living wages and human capabilities. Source: Carr et al. (2018)

\subsection{Wages and Employee Engagement}

Work engagement is a widely researched construct that has significant links to work motivation and motivational behaviour, and it is an important concept for organisations due to its positive impact on performance outcomes (Christian et al. 2011). Studies by both practitioners and academics have shown that a disengaged workforce is costly (Rayton et al. 2012). Bakker et al. (2008, p. 187) describe engagement as "a positive, fulfilling affective-motivational state of work-related well-being that is characterized by vigour, dedication, and absorption". According to Schaufeli and Bakker (2004), work engagement has three dimensions: vigour, dedication and absorption. Vigour refers to working with a high level of energy and inclination to invest efforts. Dedication refers to working with active involvement and great enthusiasm. Absorption is defined as being fully concentrated and happily engrossed in one's work. In the same way, Kahn (1990, p. 694) notes that "in engagement, people employ and express themselves physically, cognitively and emotionally during role performance". However, work engagement has been defined both attitudinally and behaviourally (Macey and Schneider 2008), and there is still some debate as to whether it is best viewed as attitude or behaviour. There is no evidence that there is a relationship between living wages and employee engagement. Therefore, the following hypothesis was brought forward:

Hypothesis $\mathrm{H} 1$ The relationship between living wages and employee engagement is cubic. 


\subsection{Wages and Job Satisfaction}

Job satisfaction has been defined as a positive emotional state resulting from the pleasure a worker derives from the job (Spector 1997). It includes the affective and cognitive attitudes held by employees about various aspects of their work (Mercer 1997). The latter implies that satisfaction is related to the component facets rather than the whole job, which is consistent with Spector's (1997) view. Judge et al. (2010) found a nexus between pay and job satisfaction. The relationship between pay and job satisfaction: employees who are satisfied with their job will normally demonstrate a high commitment to their organisation (Bai et al. 2006). Job satisfaction is the fairly stable, affective evaluation of the global job or of various aspects of the job by the employee (Spector 1997), determined to an important extent by work contextual factors (Elovainio et al. 2000). This makes job satisfaction a relevant dependent variable for this study.

Some research has shown a linear relationship between wages and capabilities like job satisfaction, and that employees who earn lower wages are not satisfied (Barnes and Collier 2013; Robbins and Judge 2017; Yalabik et al. 2017). On the contrary, a study conducted in New Zealand and South Africa showed a cubic relationship between a living wage and fairness, which is a dimension of job satisfaction, and that employees who earned below a certain threshold were disaffected (Carr et al. 2018). There is no evidence that there is a relationship between living wages and job satisfaction. Therefore, we hypothesised that:

H2 The relationship between living wages and job satisfaction is cubic.

\subsection{Relationship Between Living Wage, Employee Engagement and Job Satisfaction, with Union Membership as the Moderator}

Section 23 of the Constitution of South Africa of 1996 states that it is fair labour practice for employees to be unionised, and Section 18 further states that employees have the right to associate with any union of their choice (Van Niekerk et al. 2016). Trade unions are independent organisations that represent workers to their employers. Rights of joining the union and fairness are also enshrined in the Labour Relations Act, No. 55 of 1995 (Bendix 2015). Trade unions are an important force in South Africa, with 3.1 million members representing 25\% of the formal workforce (Mywage 2019). There is consensus in South African and international research that unionised employees are engaged and satisfied because they are paid living and decent wages (Charman and Owen 2014; Venter and Levy 2015; Laroche 2016; Maiorescu 2016; Nienaber and Martins 2016; Maleka 2018). The need for workers to earn a wage that they can live on can emerge from unions (Prowse et al. 2017). Missing in the South African literature is a study that measures whether the relationships between living wage, employee engagement and job satisfaction, as well as union membership as the moderating variable, are cubic. We hypothesised that: 
H3 Union membership moderates the cubic relationship between living wages and employee engagement.

H4 Union membership moderates the cubic relationship between living wages and job satisfaction.

The next section presents the research methods followed in this study to address the study hypotheses.

\section{Research Methodology}

\subsection{Participants}

The research design applicable for this study was descriptive, exploratory and a cross-sectional survey (Babbie 2013; Bless et al. 2013). The participants, who earned a low wage (i.e. the majority earning around R2400), were approached and purposive sampling was used (Maleka et al. 2017) at a Mall in Tshwane, which is in line with a study conducted in Canada (Phillips and Wong 2017). One thousand $(N=1000)$ questionnaires were printed and given to the field workers. Only $877(n=877)$ participants completed the questionnaires, giving a response rate of $87.70 \%$. Since participants were selected through purposive sampling outside the mall and the sampling was not representative, the results cannot be generalised to the population (Christensen et al. 2013). Data on the histogram, not displayed in this paper, showed that the participants earned R7063.06 on average, and the outliers were employees who earned between R20,000.00 and R40,000.00.

In this study, there were 877 respondents, of whom $47.90 \%(n=420)$ were male, $51.80 \%(n=454)$ were female and $0.3 \%(n=3)$ did not disclose their gender. The majority of the respondents $(n=729)$ were aged between 18 and 44 years, while $16.88 \%(n=148)$ were aged between 44 and 65 years. Two hundred and sixteen $(n=216)$ respondents indicated that they received bonuses, and 269 indicated that they were paid for working overtime. Most of the respondents $(n=516)$ had between one and four persons in their household, while $41.05 \%(n=361)$ had five or more persons in their household.

\subsection{Measures}

\subsubsection{Employee Engagement}

The questionnaire of Schaufeli et al. (2002) on employee engagement, comprising three items about vigour, three items about dedication and three items about absorption, was used. Employee engagement was measured on a seven-point scale, where 0 was never, 1 was almost never, 2 was rarely, 3 was sometimes, 4 was often, 5 was very often and 6 was always. Examples of the items are: "At my work, I feel bursting with energy", "I am enthusiastic about my job" and "I feel happy when I am 
working intensely". The mean score was 3.16 and standard deviation was 1.34 , suggesting that respondents were not engaged. The Cronbach's alpha was 0.92 .

\subsubsection{Job Satisfaction}

Nine items (three items about supervision satisfaction, three items about co-worker satisfaction and three items about rewards satisfaction) were taken from a job satisfaction scale developed by Spector (1985). Examples of the items are: "My supervisor is not quite competent in doing his/her job", "I don't feel like the work I do is appreciated" and "There is too much fighting at work". The Cronbach's alpha was 0.82 . The mean score $(M=2.47)$ and standard deviation $(\mathrm{SD}=1.01)$ were below the mid-point of 3, suggesting that the respondents were not satisfied. Maree (2016) argues that constructs with a Cronbach's alpha between 0.60 and 0.90 are reliable. The questionnaire was also presented to the faculty's research ethics committee for ethical clearance.

\subsection{Validity}

Face validity was achieved by pretesting the questionnaire on 20 respondents (Kumar 2014; Leedy and Ormrod 2015), and content validity was achieved by presenting the questionnaire to human resource management experts (Spector 2012). Exploratory factory analysis was conducted to achieve construct validity (Struwig and Stead 2013).

\subsection{Data Analysis}

The data were coded in Excel and exported into Statistical Package for the Social Sciences (SPSS) version 25 for analysis (Field 2018). The descriptive statistics comprised frequencies, means and standard deviation (Hair et al. 2014). As in Carr et al. (2018), curve estimations (i.e. linear, quadratics and S-shaped) were conducted to address the study hypotheses. Loess curves were used in this current study to graphically show the relationship between the living wage, employee engagement and job satisfaction. A Loess curve is a nonparametric statistic used to display the data graphically, and it is more effective than other curve estimations because "Loess" is derived from "local regression", and the entire procedure is a fairly direct generalisation of traditional least-squares methods for data analysis (Jacoby 2000).

\section{Results}

\subsection{Factor Analysis}

Discussed in this section are the results, which comprise factor analysis and curve estimation. The data are displayed using Loess curves. Displayed in Table 1 are 
Table 1 Factor analysis

Items

Employee Job satisfaction engagement

\begin{tabular}{|c|c|c|}
\hline My job inspires me & 0.843 & \\
\hline I am enthusiastic about my job & 0.826 & \\
\hline I am proud of the work that I do & 0.821 & \\
\hline When I get up in the morning, I feel like going to work & 0.795 & \\
\hline When I am working, I forget everything else around me & 0.778 & \\
\hline At my work, I feel bursting with energy & 0.733 & \\
\hline I can continue working for very long periods at a time & 0.706 & \\
\hline I feel happy when I am working intensely & 0.696 & \\
\hline Time flies when I'm working & 0.691 & \\
\hline $\begin{array}{l}\text { When I do a good job, I don't receive the recognition for it that I should } \\
\text { receive }\end{array}$ & & 0.783 \\
\hline My supervisor is unfair to me & & 0.750 \\
\hline My supervisor shows little interest in the feelings of subordinates & & 0.737 \\
\hline I don't feel like the work I do is appreciated & & 0.723 \\
\hline My supervisor is not quite competent in doing his/her job & & 0.660 \\
\hline $\begin{array}{l}\text { I find I have to work harder at my work than I should because of the } \\
\text { incompetence of the people I work with }\end{array}$ & & 0.546 \\
\hline There are few rewards for those who work here & & 0.508 \\
\hline I don't like the people I work with & & 0.465 \\
\hline There is too much fighting at work & & 0.389 \\
\hline Variance $\%$ & 38.37 & 12.88 \\
\hline
\end{tabular}

Extraction method: principal component analysis

Rotation method: oblimin with Kaiser normalisation

a. Rotation converged in four iterations

the 18 items of employee engagement and job satisfaction that were subjected to principal components analysis in SPSS version 25. As suggested by Field (2018), the suitability of conducting factor analysis was assessed and 0.3 was used as a cut-off to include coefficient or factor loadings. The Kaiser-Meyer-Olkin result of 0.91 was meritorious (Hair et al. 2014), and Bartlett's test of sphericity was statistically significant $(p=0.00)$ (Pallant 2016). The two-factor model explained an overall variance of $51.25 \%$, with Factor 1 (employee engagement) contributing $38.37 \%$ and Factor 2 (job satisfaction) contributing $12.88 \%$ of the variance. The employee engagement item or variable with the highest loading was "My job inspires me", and the job satisfaction item or variable with the highest loading was "When I do a good job, I don't receive the recognition for it that I should receive". There was a moderate positive correlation between employee engagement and job satisfaction $(r=0.41)$. The data in Table 1 showed that the two factors (employee engagement and job satisfaction) were unidimensional, in line with the literature (Spector 1985; Schaufeli et al. 2002). 
Table 2 Relationship between a living wage and employee engagement

\begin{tabular}{lllll}
\hline Equation & R-squared & $F$ & $d f$ & Sig \\
\hline Linear & 0.05 & 36.47 & 1 & 0.00 \\
Quadric & 0.08 & 31.73 & 2 & 0.00 \\
Cubic & 0.12 & 32.54 & 3 & 0.00 \\
\hline
\end{tabular}

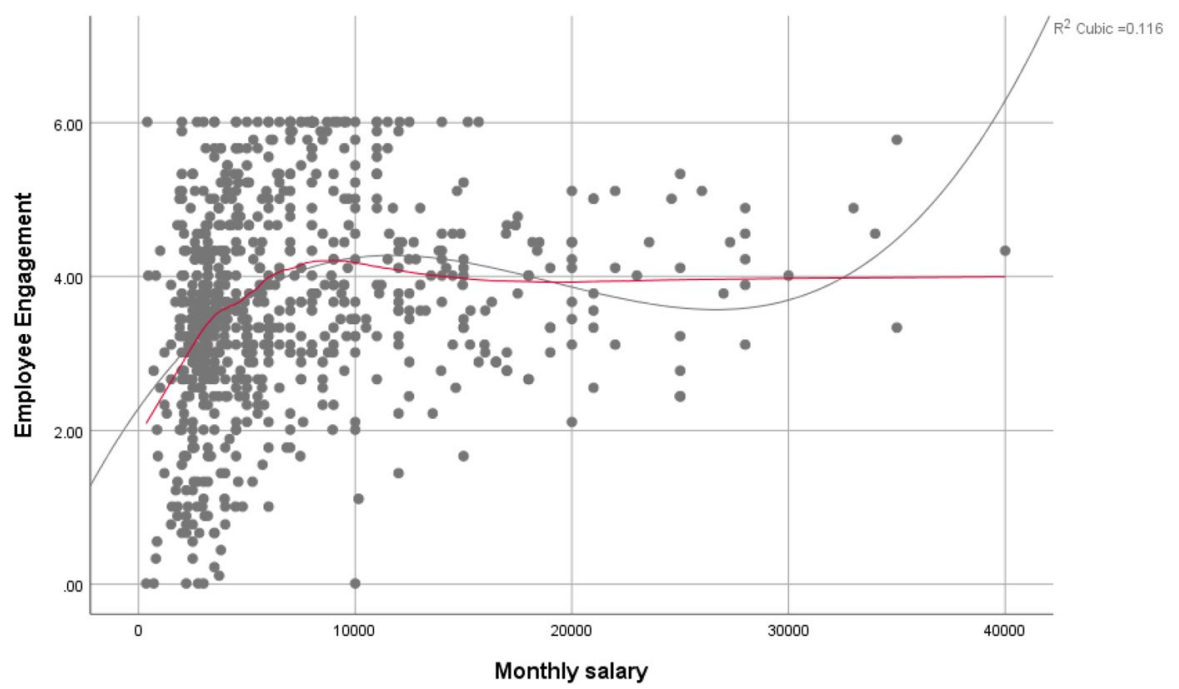

Fig. 2 Living wage and employee engagement

\subsection{Curve Estimation}

\subsubsection{Living Wage and Employee Engagement}

A summary of the curve estimation model is displayed in Table 2. Since the cubic R-squared was the highest, it can be argued that this was the line that fitted the data the best.

Figure 2 shows the relationship between a living wage and employee engagement. The data of the relationship between the living and job satisfaction are displayed in Fig. 2. A Loess curve was used, represented by a red line. Figure 2 shows a spike or upward trend between R0.00 and R10,000. It can be observed that the data reached a threshold or 4-mid-point at around R7000, suggesting that the employees earning less than R7000 were not engaged. There was slight downward diminishing engagement from R7000 to R12,500, but the Loess curve did not go below the 4-mid-point. 
Table 3 Model summary of a living wage and job satisfaction

\begin{tabular}{llrll}
\hline Equation & R-squared & \multicolumn{1}{l}{$F$} & $d f$ & Sig \\
\hline Linear & 0.12 & 106.44 & 1 & 0.00 \\
Quadric & 0.20 & 91.13 & 2 & 0.00 \\
Cubic & 0.21 & 67.62 & 3 & 0.00 \\
\hline
\end{tabular}

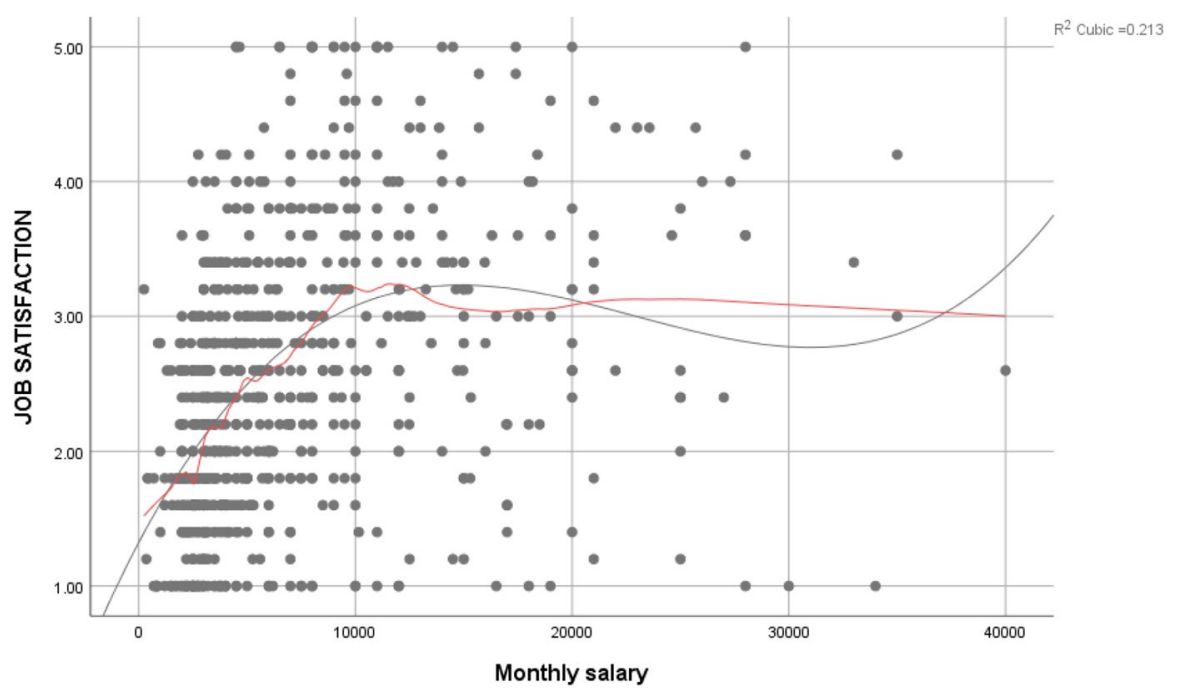

Fig. 3 Relationship between a living wage and job satisfaction

\subsubsection{Relationship Between Living Wage and Job Satisfaction}

Table 3 displays a summary of a curve estimation model. Since the cubic R-squared was the highest, it can be argued that it fitted the data the best.

In Fig. 3, the data of the relationship between the living wage and job satisfaction are displayed. A Loess curve was used, represented by a red line. The figure shows an upward trend between R0.00 and R10,000. It can be observed that the data reached a threshold or 3-mid-point at R10,000, suggesting that the employees earning less than R10,000 were dissatisfied with their wages. Between R10,000 and R20,000, the employees' level of job satisfaction diminished, but was still above the mid-point of 3-which suggests that employees earning $\mathrm{R} 10,000$ and above were satisfied with their wages. 
Table 4 Union membership moderates living wage and employee engagement

\begin{tabular}{llllll}
\hline $\begin{array}{l}\text { Union mem- } \\
\text { bership }\end{array}$ & Equation & R-squared & $F$ & $d f$ & Sig \\
\hline Yes & Linear & 0.04 & 9.38 & 1 & 0.02 \\
& Quadric & 0.03 & 4.86 & 2 & 0.00 \\
\multirow{2}{*}{ No } & Cubic & 0.06 & 4.80 & 3 & 0.00 \\
& Linear & 0.04 & 22.11 & 1 & 0.00 \\
& Quadric & 0.10 & 22.34 & 2 & 0.00 \\
& Cubic & 0.17 & 32.39 & 3 & 0.00 \\
\hline
\end{tabular}

\subsubsection{Union Membership Moderates Living Wages and Engagement}

A summary of a curve estimation model is displayed in Table 4. Since the cubic R-squared was the highest for employees who were unionised and not unionised, it can be argued that it was the line that fitted the data the best.

The data of the relationship between the living wage and employee engagement moderating for union membership are displayed in Fig. 4. A Loess curve was used, represented by a red line. The figure shows a spike or upward trend between R0.00 and R10,000. It can be observed that the data reached a threshold or 3-mid-point at R10,000, suggesting that the employees earning less than R10,000 were dissatisfied with their wages. Between R10,000 and R20,000, the employees' job satisfaction diminished, but remained above the mid-point of 3-which suggests that employees earning R10,000 and above were satisfied with their wages.

The data of the relationship between a living wage and employee engagement, moderating for union members, are displayed in Fig. 5. A Loess curve was used,

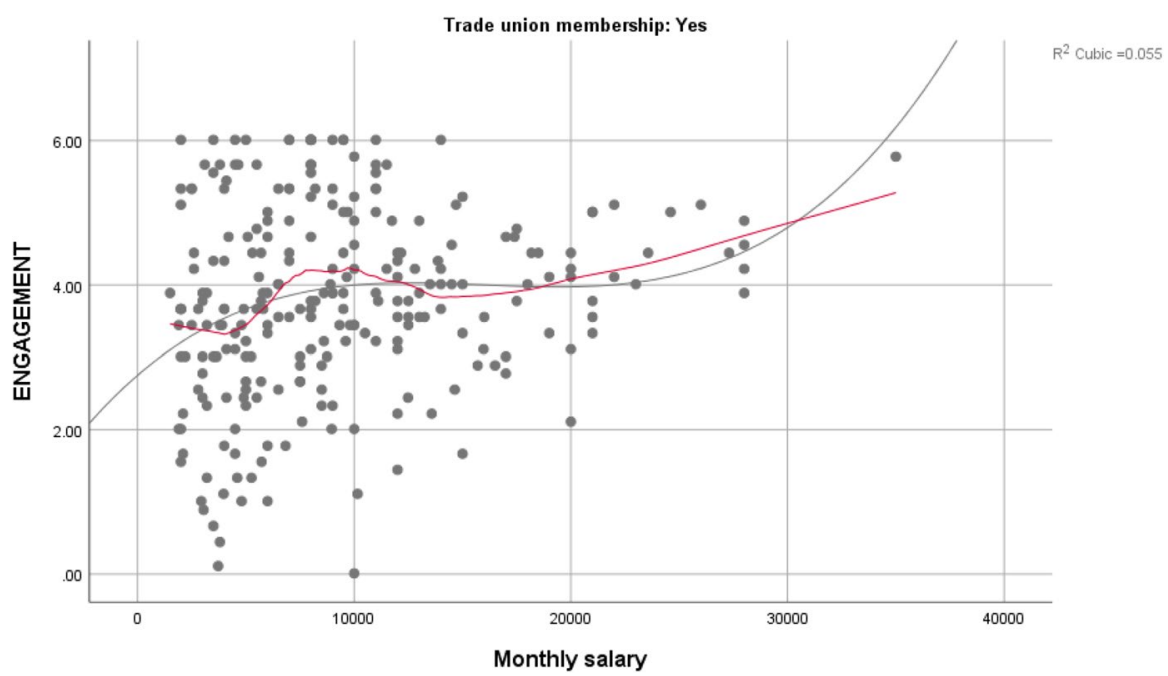

Fig. 4 Living wage and employee engagement, controlling for unionised members 


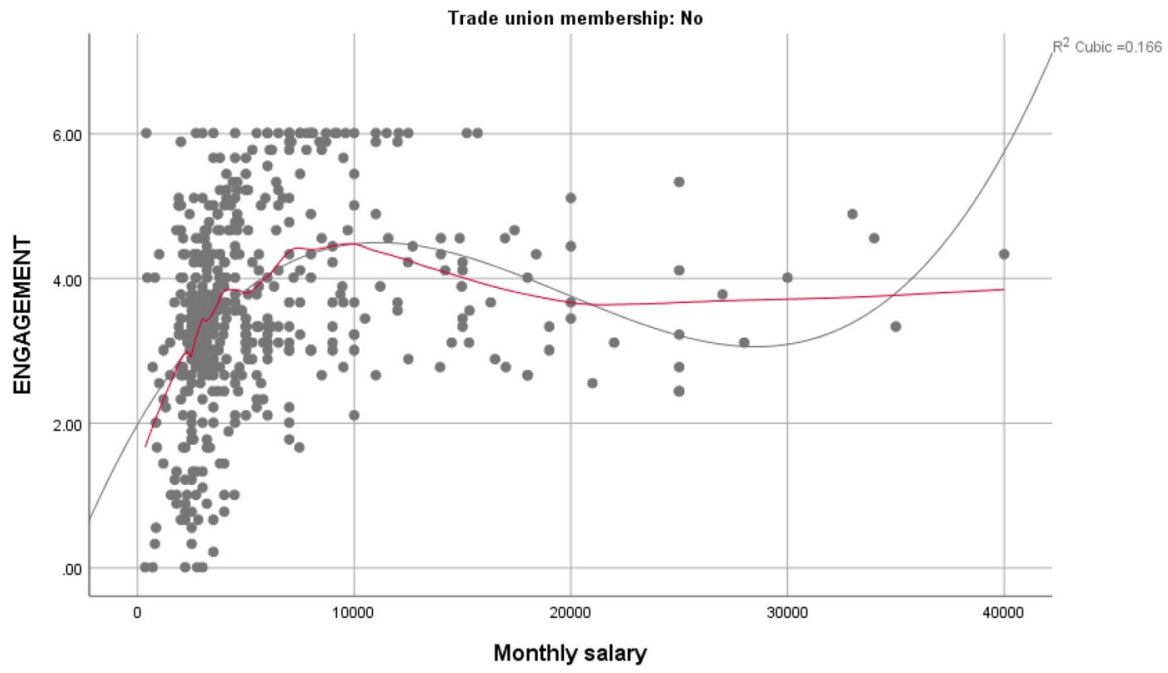

Fig. 5 Living wage and employee engagement, controlling for non-unionised members

represented by a red line. The figure shows a spike or upward trend between R0.00 and R10,000. It can be observed that the data reached a threshold or 3-mid-point at R10,000, suggesting that the employees earning less than R10,000 were dissatisfied with their wages. Between R10,000 and R20,000, the employees' job satisfaction diminished, but it remained above the mid-point of 3-which suggests that employees earning R10,000 and above were satisfied with their wages.

\subsubsection{Union Membership as a Moderator Between Living Wages and Job Satisfaction}

The data in Table 5 showed that the cubic R-squared was the highest for employees who were unionised and not unionised; therefore, it can be argued that it was the line that fitted the data best.

Since there were few employees who earned over R20,000, they were excluded during the analysis of how union membership moderated the relationship between a living wage and job satisfaction.

Table 5 Model summary for trade union as a control variable

\begin{tabular}{llllll}
\hline $\begin{array}{l}\text { Union mem- } \\
\text { bership }\end{array}$ & Equation & R-squared & $F$ & $d f$ & Sig \\
\hline Yes & Linear & 0.32 & 25.72 & 1 & 0.00 \\
& Quadric & 0.15 & 20.74 & 2 & 0.00 \\
& Cubic & 0.39 & 13.78 & 3 & 0.00 \\
\multirow{2}{*}{ No } & Linear & 0.38 & 78.41 & 1 & 0.00 \\
& Quadric & 0.20 & 54.54 & 2 & 0.00 \\
& Cubic & 0.43 & 36.59 & 3 & 0.00 \\
\hline
\end{tabular}


Table 6 Summary of the tested hypotheses

\begin{tabular}{ll}
\hline Hypotheses & Accepted/rejected \\
\hline H1: The relationship between living wages and employee engagement is cubic & Accepted \\
H2: The relationship between living wages and job satisfaction is cubic & Accepted \\
H3: Union membership moderates the cubic relationship between living wages and & Accepted \\
employee engagement & \\
$\begin{array}{l}\text { H4: Union membership moderates the cubic relationship between living wages and } \\
\text { job satisfaction }\end{array}$ & Accepted \\
\hline
\end{tabular}

A summary of the tested hypotheses is presented in Table 6.

\section{Discussion}

This paper explored the relationship between a living wage, job satisfaction and employee engagement, with union membership as the moderator. Sellers (2017) also found a link between union membership and living wages. Unionised employees are engaged and satisfied because they are paid living and decent wages (Charman and Owen 2014; Venter and Levy 2015; Laroche 2016; Maiorescu 2016; Nienaber and Martins 2016; Maleka 2018), which concurs with the findings in this study. However, in the current study, the relationships between living wage, employee engagement and job satisfaction, with union membership as the moderating variable, were cubic. Some research has shown a linear relationship between wages and capabilities like job satisfaction, and that employees who earn lower wages are not satisfied (Barnes and Collier 2013; Robbins and Judge 2017; Yalabik et al. 2017). On the contrary, a study conducted in New Zealand and South Africa showed a cubic relationship between a living wage and fairness, which is a dimension of job satisfaction, and that employees who earned below a certain threshold were disaffected (Carr et al. 2018). This finding of Carr et al. (2018) concurs with the cubic relationships between the variables in this study.

This study made both theoretical and practical contributions. In terms of the former, this was a pioneering study within BRICS that confirmed the poverty trap and diminishing returns theories. It showed that employees who earned below the threshold of R10,000 had lower engagement and satisfaction levels. The poverty theory states that employees who are earning below a threshold are impoverished (Carr et al. 2018) because they earn less than $\$ 1.90$ per day (Maleka et al. 2019). It has been found that employees who earn poverty wages embark on counterproductive activities like taking out unsecured loans, on which they are charged exorbitant interest rates (Maleka 2016). As in another study conducted in New Zealand and South Africa that measured the relationship between living and pay fairness (Carr et al. 2018), a diminishing trend was experienced after R10,000.

Practically, this study showed that union membership had a moderating effect on employees' satisfaction and engagement levels. The data (refer to Figs. 6, 7) showed that the relationship between living wages and satisfaction was higher 


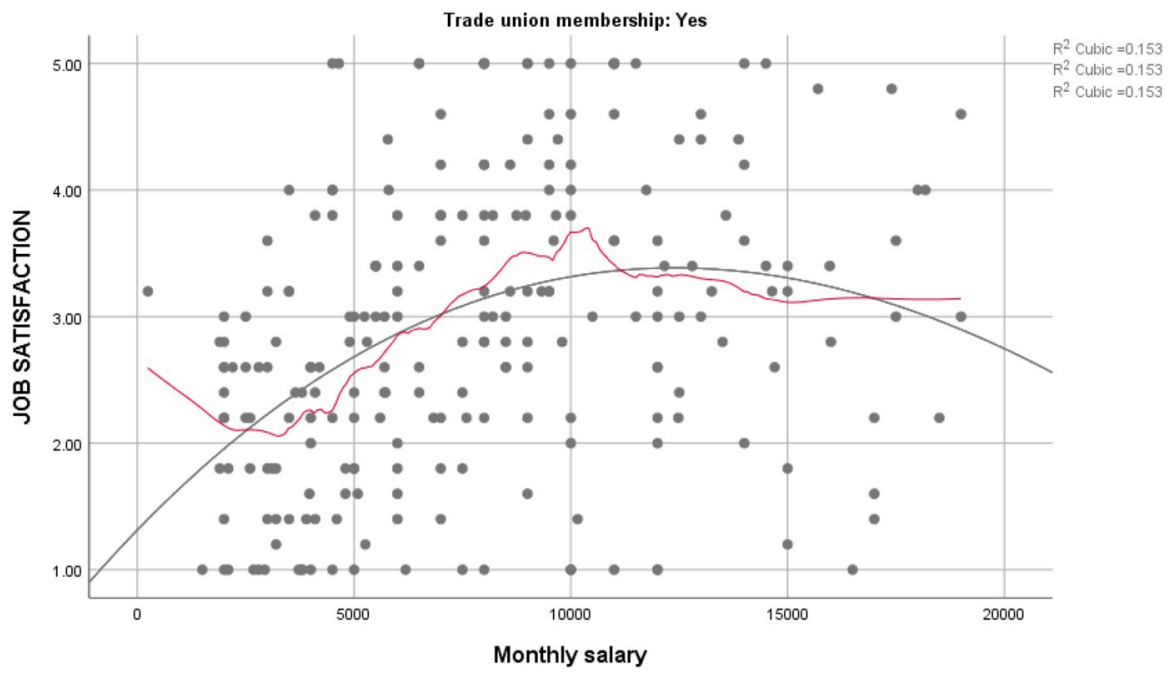

Fig. 6 Living wage and employee job satisfaction, controlling for unionised members

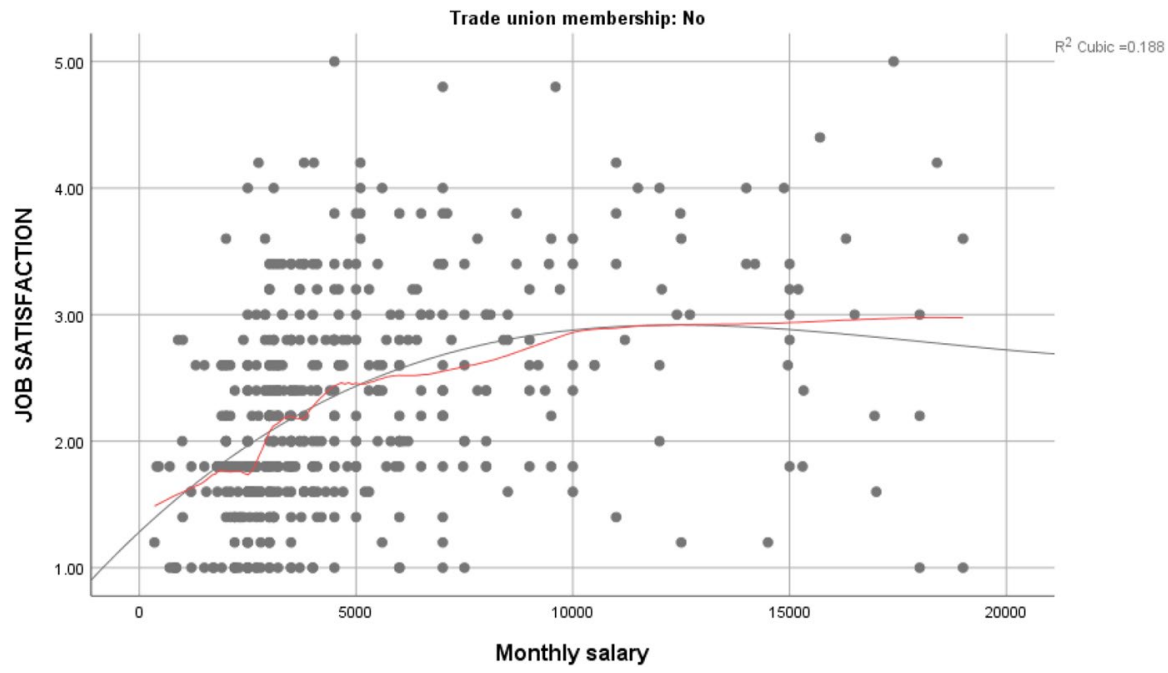

Fig. 7 Living wage and job satisfaction, controlling for non-unionised members

for unionised employees as compared to non-unionised employees. This seems to suggest that unions negotiate for higher wages, which ultimately leads to higher job satisfaction. This might pose challenges for employers who cannot afford the salary increase jump from R2400 to R10,000, and previously in the mining sector in South Africa, this ultimately led to a broken employer-employee relationship where employees embarked on long strikes that adversely impacted the production schedule (Dlangamandla et al. 2013) and GDP. With the exception of Fig. 4, the data showed that, after the Loess curve passed the mid-point, 
the living wages did not increase employees' engagement and satisfaction levels. This finding is significant for managers and trade union representatives.

A practical managerial implication is that employers can now develop a sense of awareness of the relationship between employee engagement, job satisfaction and living wages in order to effectively manage low-income workers. The role of union membership should be taken into consideration when strategising in the work environment of low-income workers. Kurucz et al. (2008) describe the ability of organisations that pay living wages as a means to brand themselves as living wage employers. These organisations have a competitive advantage over industry rivals, fitting the competitive advantage model. Some of the benefits derived from earning a living wage include more time and money for family, a decreased need to hold multiple jobs, and more time and finances to support education upgrades as well as to participate in community organisations (Luce 2004). Prowse et al. (2017) found a link between wage and union membership. Carr et al. (2018) found that the relationship between a living wage and fairness, which is a dimension of job satisfaction, was cubic and that employees who earned below a certain threshold were disaffected. It is important to note that the relationships in this study were cubic and not linear.

Even though this study made theoretical and practical contributions, it had its limitations. Firstly, a non-probability sampling technique was used to select participants; hence, its results cannot be generalised. Also, the research instrument did not include economic sectors. This would have given a clear picture as to where the majority of the respondents came from. Previous research has revealed that employees in Tshwane work precarious jobs or jobs that are not permanent in the domestic, retail and financial sectors where they are paid lower wages (Maleka et al. 2019). Conducting a cross-sectional study gives only a snapshot picture of the results.

For future research, it is suggested that a study be conducted on the demographic differences (e.g. gender, employment status, educational level, tenure, age, household number and income before and after wage deductions) of how low-income workers perceive living wage, job satisfaction and employee engagement. It is also recommended that future research measure how additional pay like overtime affects the relationship between employee engagement and job satisfaction. Another study should focus on how living wages influence productivity. The role of union membership can be investigated by conducting a qualitative study among low-income workers.

The following are the recommendations for employers and trade union members:

a. The living wage established in this study should be implemented, based on the affordability of the employers.

b. Awareness campaigns of the link between union membership, living wage, job satisfaction and employee engagement should be further explored in different kinds of originations in another big city in South Africa.

c. The role of union membership must also be incorporated in strategies for improving effectiveness and harmony in relationships in the workplace. 


\section{Conclusions}

There is a need for a current understanding of the dynamics between union membership, living wage, job satisfaction and employee engagement. This paper addressed this research gap by examining the relationship between living wages and employee engagement, which was found to be cubic, with union membership as the moderator. This finding can help management to predict behavioural responses by paying attention to job satisfaction, employee engagement, living wages and union membership. This also has the potential to influence collective bargaining processes. Therefore, it is essential that management develop a sense of awareness of the relationship between employee engagement, job satisfaction and living wages, and the influence of union membership. This will enable a better understanding of low-income workers and facilitate the "how to" of effectively managing and relating to these workers. The findings of this study make an important contribution to the limited existing literature on living wages.

Funding In 2018 Dr. M.J. Maleka received R25 000.00 National Research Fund, Knowledge, Interchange and Collaboration grant to host Prof. S. Carr from Massey University in Cape Town. Prof. Carr conceptualised the study and trained Dr. MJ. Maleka how to conduct the statistical analysis in SPSS.

\section{Declarations}

Conflict of interest The authors declare that they have no conflicts of interest.

Open Access This article is licensed under a Creative Commons Attribution 4.0 International License, which permits use, sharing, adaptation, distribution and reproduction in any medium or format, as long as you give appropriate credit to the original author(s) and the source, provide a link to the Creative Commons licence, and indicate if changes were made. The images or other third party material in this article are included in the article's Creative Commons licence, unless indicated otherwise in a credit line to the material. If material is not included in the article's Creative Commons licence and your intended use is not permitted by statutory regulation or exceeds the permitted use, you will need to obtain permission directly from the copyright holder. To view a copy of this licence, visit http://creativecommons.org/licen ses/by/4.0/.

\section{References}

Anker, R. 2011. Conditions of Work and Employment Programme. Geneva: International Labour Office. Anker, R. and M. Anker. 2013. Global Living Wage Coalition. Retrieved September 16, 2019, from https://www.fairtrade-deutschland.de/fileadmin/DE/01_was_ist_fairtrade/03_standards/textile_stand ard_anker_methodology.pdf.

Anker, R., and M. Anker. 2017. Living Wages Around the World: Manual for Measurement. Sussex: Elgar.

Babbie, E. 2013. The Practice Of Social Research. Belmont, CA: Wadsworth Cengage.

Bai, B., K.P. Brewer, G. Sammons, and S. Swerdlow. 2006. Job Satisfaction, Organizational Commitment, and Internal Service Quality: A Case Study of Las Vegas Hotel/Casino Industry. Journal of Human Resource in Hospitality and Tourism 5 (2): 37-54.

Bakker, A.B., W.B. Schaufeli, M.P. Leiter, and T.W. Taris. 2008. Work Engagement: An Emerging Concept in Occupational Health Psychology. Work and Stress 22 (3): 187-200. 
Barnes, D.C., and J.E. Collier. 2013. Investigating Work Engagement in the Service Environment. Journal of Services Marketing 27 (6): 485-499.

Bendix, S. 2015. Labour Relations: A Southern African Perspective, 6th ed. Cape Town: Juta.

Bless, C., C. Higson-Smith, and L. Sithole. 2013. Fundamentals of Social Research Methods, 5th ed. Cape Town: Juta.

Carr, S.C., M.J. Maleka, I. Meyer, M.L. Barry, J. Haar, J. Parker, and A. Naithani. 2018. How Can Wages Sustain a Living? By Getting Ahead of the Curve. Sustainability Science 13 (4): 901-917.

Chang, J., A. Travaglione, and G. O’Neill. 2017. Job Attitudes Between Unionized and Nonunionized Employees. International Journal of Organizational Analysis 25 (4): 647-661.

Charman, C., and A.L. Owen. 2014. Collective Happiness: Labour Union Membership and Life Satisfaction. Applied Economics Letters 21 (13): 924-927.

Christian, M.S., A.S. Garza, and J.E. Slaughter. 2011. Work Engagement: A Quantitative Review and Test of Its Relations with Task and Contextual Performance. Personnel Psychology 64 (1): 89-136.

Christensen, L.B., R.B. Johnson, and L.A. Turner. 2015. Research methods, design and analysis, 12 th ed. Boston, MA: Pearson.

Cowherd, D., and D. Levine. 1992. Product Quality and Pay Equity Between Lower-Level Employees and Top Management: An Investigation of Distributive Justice Theory. Administrative Science Quarterly 37 (2): 302-320.

Dlangamandla, F., T. Jika, L. Ledwaba, S. Mosamo, A. Saba, and L. Sadiki (eds.). 2013. We are going to kill each other today: The Marikana story. Tafelberg, Cape Town.

Elovainio, M., M. Kivimaki, N. Steen, and T. Kalliomaki-Levanto. 2000. Organizational and Individual Factors Affecting Mental Health and Job Satisfaction: A Multilevel Analysis of Job Control and Personality. Journal of Occupational Health Psychology 5 (2): 269-277.

Field, A. 2018. Discovering Statistics Using IBM SPSS Statistics, 5th ed. London: Sage.

Figart, D.M. 2001. Ethical Foundations of the Contemporary Living Wage Movement. International Journal of Social Economics 28 (10/11/12): 800-814.

Ford, M., and M. Gillan. 2017. In Search of a Living Wage in Southeast Asia. Employee Relations 39 (6): 903-914.

George, J.M. 1989. Mood and absence. Journal of Applied Psychology 74: 317-324.

Green, C., and J. Heywood. 2015. Dissatisfied Union Workers: Sorting Revisited. British Journal of Industrial Relations 53 (3): 580-600.

Hair, J.F., W.C. Black, B.J. Babin, and R.E. Anderson. 2014. Multivariate Data Analysis. Harlow: Pearson.

Hammer, T., and A. Avgar. 2005. The Impact of Unions on Job Satisfaction, Organizational Commitment, and Turnover. Journal of Labor Research 26 (2): 241-266.

Jacoby, W.G. 2000. LOESS: A Nonparametric, Graphical Tool for Depicting Relationships Between Variables. Electoral Studies 19 (4): 577-613.

Judge, T.A., C.J. Thoresen, J.E. Bono, and G.K. Patton. 2010. The Relationship between Pay and Job Satisfaction: A Meta-Analysis of the Literature. Journal of Vocational Behavior 77 (2): 157-167.

Kahn, W.A. 1990. Psychological Conditions of Personal Engagement and Disengagement at Work. Academy of Management Journal 33 (4): 692-724.

Kumar, M. J. 2018. Top 3 Theories of Wages. Retrieved September 16, 2019, from http://www.econo micsdiscussion.net/wages/top-3-theories-of-wages-with-diagram/7446.

Kumar, R. 2014. Research Methodology. London: Sage.

Kurucz, E.C., B.A. Colbert, and D. Wheeler. 2008. The Business Case for Corporate Social Responsibility. In The Oxford Handbook of Corporate Social Responsibility, ed. A. Crane, D. Matten, A. McWilliams, J. Moon, and D.S. Siegel, 83-112. Oxford, NY: Oxford University Press.

Laroche, P. 2016. A Meta-Analysis of the Union-Job Satisfaction Relationship. British Journal of Labour Relations 54 (4): 709-741.

Laroche, P. 2017. Research Shows Unionized Workers Are Less Happy, but Why?. Harvard Business Review. Retrieved September 16, 2019, from https://hbr.org/2017/08/research-shows-unionizedworkers-are-less-happy-but-why.

Leedy, P.D., and J.E. Ormrod. 2015. Practical Research: Planning and Design. Boston, MA: Pearson.

Leete, L. 2000. Wage Equity and Employee Motivation in Nonprofit and For-Profit Organizations. Journal of Economic Behavior and Organization 43 (4): 423-446.

Living Wage London. 2014. How Living Wage is Calculated. Retrieved September 16, 2019, from http:// livingwagecanada.ca/files/4814/6340/3672/calculating-living-wage-london.pdf.

Luce, S. 2004. Fighting for a Living Wage. Ithaca, NY: Cornell University Press. 
Macey, W.H., and B. Schneider. 2008. The Meaning of Employee Engagement. Industrial and Organizational Psychology 1 (1): 3-30.

Maiorescu, R.D. 2016. Using Online Platform to Engage Employees' Unionism: The Case of IBM. Public Relations Review 43 (5): 963-968.

Maleka, M. J. 2016. Narratives of Employees Visiting Tshwane Mall Who Earn Above and Below an Estimated Living Wage. Paper Presented at GBATA Conference. Dubai. 16-20 October 2016.

Maleka, M. J. 2017. Exploring the Relationship between a Living Wage and Human Resource Outcomes: Evidence from Marabastad Mall. Paper Presented at the GBATA Conference, Vienna. 11-15 July 2017.

Maleka, M.J. 2018. The Biographical and Human Resource Management Predictors of Union Membership Engagement of Low- and Middle-Income Workers. Journal of Economics and Behavioral Studies 10 (1): 207-216.

Maleka, M.J., M. Mpofu, C.K. Hlatywayo, I. Meyer, S. Carr, and J. Parker. 2019. Employee Engagement, Organisational Commitment and Job Satisfaction in Namibia, South Africa, and Zimbabwe: An Exploratory Study. Journal of Psychology in Africa 29 (4): 393-400. https://doi.org/10.1080/ 14330237.2019.1647964.

Maleka, M.J., R. Rubigbana, S. Carr, I. Meyer, M. Barry, and J. Parker. 2018. Reflection of the Living Wage in New Zealand and South Africa. London: Sage.

Maleka, M.J., C. Schultz, L. Van Hoek, L. Dachapalli, and S. Ragadu. 2017. Measuring Employee Engagement of Low-Income Workers Either Working or Visiting Marabastad Mall in the Tshwane Metropolitan Municipality. Journal of Economics and Behavioral Studies 9 (6): 74-82.

Maree, K. 2016. First steps in Research. Pretoria: Van Schaik.

Mercer, D. 1997. Job Satisfaction and the Secondary Headteacher: The Creation of a Model of Job Satisfaction. School Leadership and Management 17 (1): 57-68.

Mohr, P., D. Yu, and S. Mollentzedla. 2016. Economic indicators, 5th ed. Pretoria: Van Schaik.

Mywage. 2019. Trade Unions. Retrieved September 16, 2019, from https://mywage.co.za/decent-work/ legal-advice/unions-in-south-africa.

Nienaber, H., and N. Martins. 2016. Employee engagement in a South African context. Randburg: KR Publishing.

Pallant, J. 2016. A Step-by-Step Guide to Data Analysis Using IBM Statistics. New York: McGraw-Hill.

Phillips, R., and C. Wong, eds. 2017. Handbook of Community Well-Being Research. Dordrecht: Springer.

Plecher, H. 2019. BRIC Countries: Gross Domestic Product (GDP) Per Capita in Current Prices from 2014 to 2024 (in U.S. Dollars). Retrieved September 16, 2019, from https://www.statista.com/stati stics/741745/gross-domestic-product-gdp-per-capita-in-the-bric-countries/.

Prowse, P., A. Lopes, and R. Fells. 2017. Community and Union-Led Living Wage Campaigns. Employee Relations 39 (6): 825-839.

Rayton, B., T. Dodge, and S. D’Analeze. 2012. Employee Engagement-The Evidence. London: Engage for Success.

Renaud, S. 2002. Rethinking the Union Membership/Job Satisfaction Relationship: Some Empirical Evidence in Canada. International Journal of Manpower 23 (2): 137-150.

Robbins, S.P., and T.A. Judge. 2017. Organizational Behavior, 17th edn. Boston: Pearson.

Ryan, J.A. 1912. A Living Wage: Its Ethical and Economic Aspects. London: Macmillan.

Schaufeli, W.B., and A.B. Bakker. 2004. Job Demands, Job Resources, and Their Relationship with Burnout and Engagement: A Multi-Sample Study. Journal of Organizational Behavior 25 (3): 293-315.

Schaufeli, W.B., M. Salanova, V. Gonzalez-Romá, and A.B. Bakker. 2002. The Measurement of Engagement and Burnout: A Confirmative Analytic Approach. Journal of Happiness Studies 3: 71-92.

Sellers, P.J. 2017. The UK Living Wage: A Trade Union Perspective. Employee Relations 39 (6): 790-799.

Sen, A.K. 1987. The Standard of Living. In Tanner Lectures on Human Values, ed. G. Hawthorne, 20-38. Cambridge: Cambridge University Press.

Sen, A.K. 1992. Inequality Reexamined. Cambridge, MA: Harvard University Press.

Sen, A.K. 1999. Development as Freedom. New York: Knopf.

Spector, P. 1985. Measurement of Human Service Staff Satisfaction: Development of the Job Satisfaction Survey. American Journal of Community Psychology 13: 693-713.

Spector, P.E. 1997. Job Satisfaction: Application, Assessment, Causes, and Consequences. London: Sage. Spector, P.E. 2012. Industrial and organisational psychology. Hoboken: John Wiley \& Sons.

Struwig, F.W., and G.B. Stead. 2013. Research: Planning, Designing and Reporting. Cape Town: Pearson. 
Subramanian, D., J.M. Verd, J. Vero, and B. Zimmermann. 2013. Bringing Sen's Capability Approach to Work and Human Resource Practices. International Journal of Manpower 34 (4): 292-304.

TUC. 2016. Living on the edge. Retrieved 3 June 2018, from http://www.tuc.org.uk/economic-issues/ labour-market/livingedge.

Van Niekerk, A., N. Smit, M.A. Christianson, M. McGregor, and B.P.S. Van Eck. 2016. Law@work. Durban: LexisNexis.

Venter, R., and A. Levy, eds. 2015. Labour Relations in South Africa, 5th ed. Cape Town: Oxford University Press.

Western, B., and J. Rosenfeld. 2011. Unions, Norms, and the Rise in US Wage Inequality. American Sociologic Review 76 (4): 513-537.

Yalabik, Z.Y., B.A. Rayton, and A. Rapti. 2017. Facets of Job Satisfaction and Work Engagement. Evidence-Based HRM: A Global Forum for Empirical Scholarship 5 (3): 248-265.

Zuberi, D. 2013. Cleaning Up: How Hospital Outsourcing is Hurting Workers and Endangering Patients. Ithaca, NY: Cornell University Press.

Publisher's Note Springer Nature remains neutral with regard to jurisdictional claims in published maps and institutional affiliations.

\section{Authors and Affiliations}

\section{J. Maleka ${ }^{1}$ (D) . C. M. Schultz ${ }^{2}$ D - L. van Hoek ${ }^{2}$ L. Paul-Dachapalli ${ }^{2}$. S. C. Ragadu ${ }^{2}$}

M. J. Maleka

Malekam@tut.ac.za

L. van Hoek

vanhoekce@tut.ac.za

L. Paul-Dachapalli

paulla@tut.ac.za

S. C. Ragadu

ragadusc@tut.ac.za

1 Tshwane University of Technology, eMalahleni Campus, Private Bag X680, Pretoria 0001, South Africa

2 Department of People Management and Development, Tshwane University of Technology, Private Bag X680, Pretoria 0001, South Africa 